\title{
Assessment of Anthropogenic Impact on Surface Water Quality, South Africa
}

\author{
Dipitseng Manamela \\ Dihlashana Consulting Pty Ltd, No. 1 Maxwell Office Park, Magwa Crescent West \\ Waterfall City, Midrand, 1685 Midrand, Gauteng, South Africa \\ E-mail: dipitseng@dihlashana.co.za
}

Omotayo Awofolu (Corresponding author)

Department of Health Sciences, Faculty of Health and Applied Sciences

Namibia University of Science and Technology, PO Box 13388 NUST, Windhoek, Namibia

E-mail: oawofolu@nust.na

Received: March 18, 2017 Accepted: April 17, 2018 Published: June 19, 2018

doi:10.5296/ast.v6i1.12837 URL: https://doi.org/10.5296/ast.v6i1.12837

\begin{abstract}
This article investigates the impact of anthropogenic activities on an important surface water from physico-chemical, chemical and microbial perspectives. The surface water, referred to as Blesbokspruit is in the West Rand District of South Africa. Potential impactors include wastewater treatment plant, mines, farmlands and informal settlements. Water samples were collected from nine purposively selected sampling points and analysed in 2014. The mean values of analysed variables across sampling sites and periods ranged from $\mathrm{pH}$ : 7.4-8.4; $\mathrm{EC}$ : 93.0 - 146.6 mS/m; TSS: 11.3 - 39.0 mg/L; TDS: 590.3 - $1020.3 \mathrm{mg} / \mathrm{L}$; COD: 15.6- $34.8 \mathrm{mg} / \mathrm{L}$. Those for anions varied from $\mathrm{NO}_{3}{ }^{-}: 0.2-2.1(\mathrm{mg} / \mathrm{L}) \mathrm{N} ; \mathrm{PO}_{4}{ }^{3-}: 0.4-0.9 \mathrm{mg} / \mathrm{L}$ and $\mathrm{SO}_{4}{ }^{2-}: 118.6-$ $379.5 \mathrm{mg} / \mathrm{L}$. The metallic variables ranged from As: 0.01-0.06 mg/L; Cd: 0.02-0.06 mg/L; Fe: $0.04-0.73 \mathrm{mg} / \mathrm{L} ; \mathrm{Cu}: 0.02-0.05 \mathrm{mg} / \mathrm{L}$ and $\mathrm{Zn}: 0.05-0.15 \mathrm{mg} / \mathrm{L}$. The Faecal coliform varied from 15.9-16878.5 cfu/100 ml; Total coliform: 92.9-430294 cfu/100 ml and HPC from 4322.5-39776 cfu/1ml. Detection of toxic metals and pathogenic organisms above target safety limits indicate unsuitability of the water for domestic use with impact on the health of aquatic ecosystem. The study generally revealed the impact of anthropogenic activities on the surface water quality.
\end{abstract}

Keywords: Trace metals, pathogens, anthropogenic, water quality, South Africa 


\section{Introduction}

Continual monitoring and protection of the quality of water resources is usually strategic especially in arid and semi-arid countries such as South Africa. Hence, activities that may negatively impact and diminish the quality of these resources should be prevented. Surface waters such as rivers, lakes and streams are major sources of water utilised for irrigational, industrial, recreational as well as domestic activities including the informal settlers where there is no access to potable water supply. The quality of natural water resources can be impacted because of rapid economic development, urbanisation and anthropogenic activities (Masere et al., 2012). Factors such as run-offs from agricultural farmland, discharges from wastewater treatment plants and industrial effluent and illegal dumping of wastes into the water systems are among major sources of concern on quality of surface waters (Nartey et al., 2012).

Polluted water is one of the major causes of human disease and health problems. Incidences of contamination of aquatic resources by bacteria pathogens in South Africa (Pitman, 2011) and elsewhere (Keddy et al., 2011; NICD, 2016) have been reported. In addition, incidences of diarrhoea-associated illnesses can be attributable to unsafe water, inadequate sanitation and insufficient hygiene. The bacteria commonly found in polluted water are coliforms mostly from animal and human wastes and improperly treated effluent from sewage treatment plants. Some local authorities in South Africa were reported to capacity for effective sewage treatment because of the increase in population among other factors (Wall, 2006).

The Blesbokspruit drains into the Vaal River; downstream of the Vaal Dam. It forms part of the Ekurhuleni municipality in the East Rand and extends to the Lesedi Municipality in Heidelberg. The spruit is one of the water resources that are under constant threat in the Upper Vaal Water Management Area. Water pollution in this catchment has witnessed steady increase over time and the impact of anthropogenic activities on surface waters has been source of concern to the government (DWAF, 2006).

High level of trace metals such as $\mathrm{Cd}, \mathrm{As}$ and $\mathrm{Pb}$ in surface waters are of major concern to the health of aquatic ecosystem and that of human (Sanjay et al., 2010). These metals have no physiological benefits to man (Duruibe et al., 2007). Cadmium is of concern due to its carcinogenic and possible endocrine disrupting effects (Bernhoft, 2013). Environmental sources of $\mathrm{Cd}$ include wastes from Cd-based batteries, incinerators and runoff from agricultural soils where phosphate fertilizers are used. Zinc toxicity in human has been regarded as mild, however continual or prolonged ingestion of large doses can result in health complications such as fatigue, dizziness, and neutropenia (Hess and Schmid, 2002). Although, copper $(\mathrm{Cu})$ has been classified as essential element due to its involvement in some physiological processes, elevated levels have however been found to be toxic to gastrointestinal tract and the kidney (Gamakaranage et al., 2011).

The aim of the research therefore, was to investigate the impact of anthropogenic activities on the quality of the surface water commonly referred to Blesbokspruit. This was with a view of assessing possible human exposure to water as well as safety of the aquatic ecosystem. 


\section{Macrothink}

\section{Materials and Methods}

\subsection{Study Area}

The study site is the Blesbokspruit which drains into the Vaal River at Vereeniging, downstream of the Vaal dam and upstream of the barrage. The Vaal dam and the Barrage are water abstraction points by one of the major bulk water treatment and supplier in the country. Water abstracted at these points is treated for potable use and further distribution to consumers. The Blesbokspruit is within the Vaal River Water Management Catchment Area (WMCA) and have become highly altered due to urban, industrial and mining developments. These activities are most likely to have impact on the flow, level, morphology and quality of the water (Warburton et al., 2012). All these impacts may further have effects on the health of the ecosystem and various end users for domestic, irrigational and recreational activities. The map of the study area is as shown below.

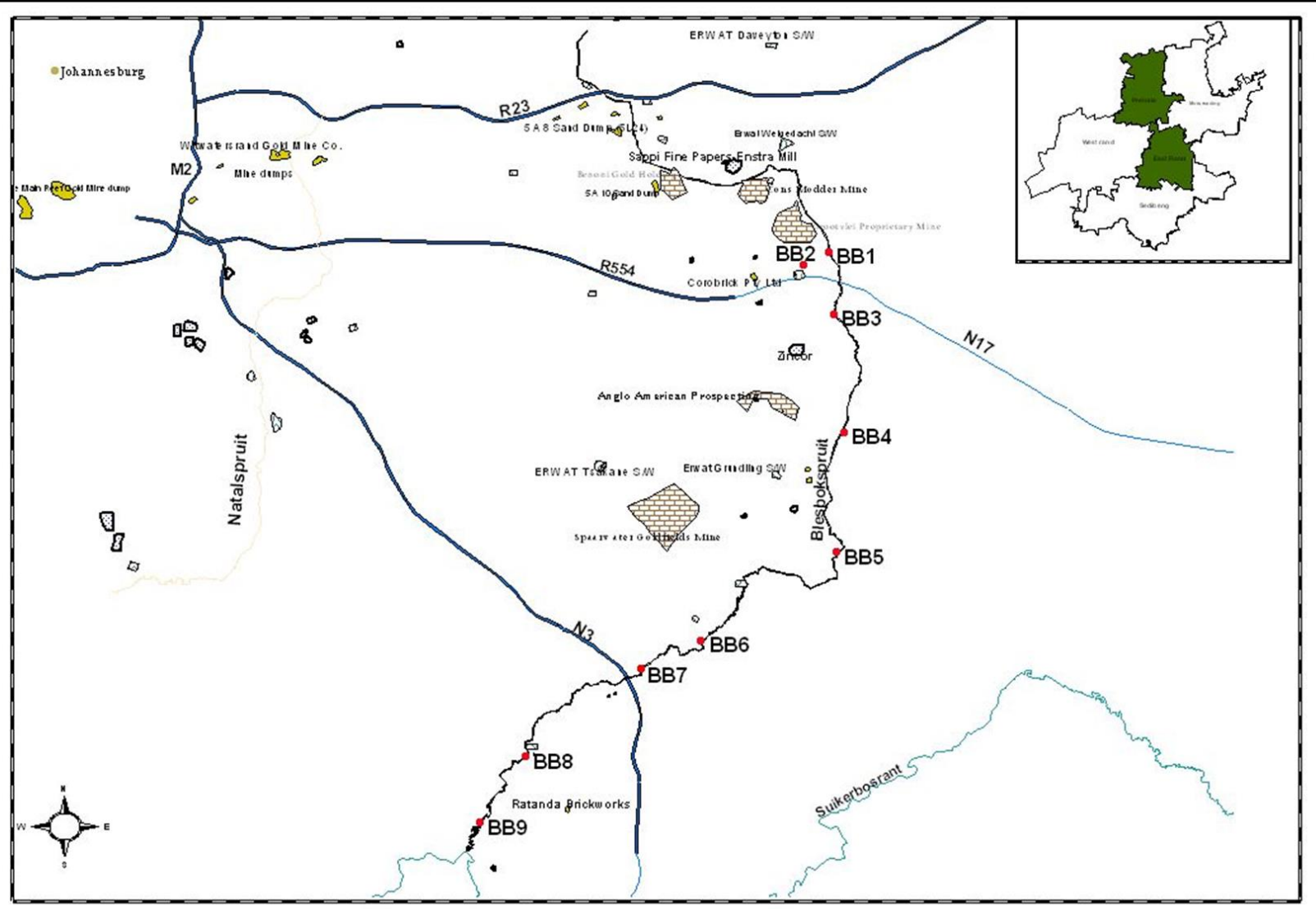

The ecology of the spruit consists of Highveld Grassland which is fast disappearing due to land use practices such as agriculture and mining. Terrestrial vegetation consists of a variety of flowering plants such as the Orange River lily (Crinum bulbispermum), plough breaker (Erythrina zeyheri) and Aloe ecklonis. The geological formation of study area is characterised by dolomitic formation as well as sedimentary rocks with sandstones and shales as the most common rock types (Hoares et al., 2008). The region is considered semi-arid with a 
temperate climatic condition typified by short winter period. The region also falls with the summer rainfall period with an average rainfall of between $670-735 \mathrm{~mm}$ per annum. However, for the Upper Vaal Area i.e. upstream of the Vaal Barrage, the mean annual temperature varies between $16^{\circ} \mathrm{C}$ to $12^{\circ} \mathrm{C}$ with an average of $15^{\circ} \mathrm{C}$ for the catchment (DWAF, 2004).

\subsection{Samples, Sampling and Sample Treatment}

Water samples were collected along the Blesbokspruit using purposive sampling technique based on identified potential impactors (i.e. anthropogenic events) along the channel of the surface water. Samples were collected once a month from nine (9) points within the vicinity of identified potential impactors. The sampling points and their co-ordinates are as presented in Table 1.

Table 1. Sample collections points on the Blesbokspruit and their co-ordinates

\begin{tabular}{|c|c|c|}
\hline Sampling Points & Co-ordinates & Site description \\
\hline B1 & $26^{\circ} 15^{\prime} 20^{\prime \prime S} ; 28^{\circ} 29^{\prime} 56^{\prime \prime} \mathrm{E}$ & $\begin{array}{l}\text { Upstream section, located around the } \\
\text { Grootvlei Mine. }\end{array}$ \\
\hline B2 & $\begin{array}{l}26^{\circ} 15^{\prime} 47^{\prime \prime} \mathrm{S} ; 28^{\circ} 29^{\prime} 03^{\prime \prime} \\
\mathrm{E}\end{array}$ & $\begin{array}{l}\text { Located on Klein Blesbokspruit downstream } \\
\text { of Erwat Ancor Sewage Works. }\end{array}$ \\
\hline B3 & $26^{\circ} 17^{\prime} 28^{\prime \prime S} ; 28^{\circ} 30^{\prime} 06^{\prime \prime} \mathrm{E}$ & $\begin{array}{l}\text { Located at the Daggafontein mines. Tailing } \\
\text { dams and old mine surrounds this point with } \\
\text { visible pipes indicating river diversion. }\end{array}$ \\
\hline B4 & $26^{\circ} 21^{\prime} 33^{\prime \prime S} ; 28^{\circ} 30^{\prime} 27^{\prime \prime} \mathrm{E}$ & $\begin{array}{l}\text { Near Marivale Bird Sanctuary; the northern } \\
\text { point is another shaft of Grootvlei mine. }\end{array}$ \\
\hline B5 & $\begin{array}{l}26^{\circ} 25^{\prime} 41.03^{\prime \prime S} ; 28^{\circ} 30^{\prime} 11 . \\
92^{\prime \prime} \mathrm{E}\end{array}$ & $\begin{array}{l}\text { Located on R51 road to Balfour which is } \\
\text { also close to mine dumps. }\end{array}$ \\
\hline B6 & $26^{\circ} 28^{\prime} 43^{\prime \prime S} ; 28^{\circ} 25^{\prime} 32^{\prime \prime} \mathrm{E}$ & $\begin{array}{l}\text { Located downstream of Erwat Herbert } \\
\text { Bickley Sewage Works. }\end{array}$ \\
\hline B7 & $26^{\circ} 30^{\prime} 30^{\prime \prime S} ; 28^{\circ} 25^{\prime} 32^{\prime \prime} \mathrm{E}$ & $\begin{array}{l}\text { Located downstream of Heidelberg town } \\
\text { and its residential areas. }\end{array}$ \\
\hline B8 & $26^{\circ} 32^{\prime} 43^{\prime \prime S} ; 28^{\circ} 19^{\prime} 28^{\prime \prime} \mathrm{E}$ & $\begin{array}{l}\text { Located downstream of Erwat Heidelberg } \\
\text { Sewage Works. }\end{array}$ \\
\hline B9 & $26^{\circ} 35^{\prime} 07^{\prime \prime S} ; 28^{\circ} 17^{\prime} 54^{\prime \prime} \mathrm{E}$ & $\begin{array}{l}\text { Downstream section located near Erwat } \\
\text { Ratanda Sewage Works. }\end{array}$ \\
\hline
\end{tabular}

Water samples were collected into cleaned acid washed 1-L Nalgene plastic containers at about $12 \mathrm{~cm}$ below the water surface from various sampling points. These were kept cool in a cooler box and transported to the laboratory for analyses. Water samples for microbiological investigations were collected in 2-L sterile glass bottles and taken immediately to the laboratory for refrigerating. Analyses were carried out within $12 \mathrm{~h}$ of sample collection.

\subsection{Sample Analysis}

2.3.1 Physico-chemical Variables 
The $\mathrm{pH}$ and temperature of the water samples were determined directly on site with the $\mathrm{pH}$ meter 330 supplied by Merck NT Laboratory (Pty) Limited. EC was also determined on site using the Radiometer Conductivity Meter Model CDM83. All on-site instruments were properly calibrated before use. Total Dissolved Solids (TDS) was determined using the vacuum, evaporating, drying and weighing method; Total Suspended Solids (TSS) in mg/L was determined using the vacuum, filtering, drying and weighing method while the COD was determined using the digestion block $\left(148{ }^{\circ} \mathrm{C} \pm 5^{\circ} \mathrm{C}\right)$ and measured using UV-Visible Spectrophotometer at $445 \mathrm{~nm}$ as previously described by Clesceri et al. (1998).

2.3.2 Nitrate $\left(\mathrm{NO}_{3}{ }^{-}\right)$, Phosphates $\left(\mathrm{PO}_{4}{ }^{3-}\right)$ and Sulphates $\left(\mathrm{SO}_{4}{ }^{2-}\right)$ Analysis in Water Samples

Nitrate determination in water samples was carried out using the TRAACS 800 equipment fitted with a $10-\mathrm{mm} \times 0.5 \mathrm{~mm}$ diameter flow cell using $520 \mathrm{~nm}$ filter. Phosphate $\left(\mathrm{PO}_{4}{ }^{3-}\right)$ and sulphate $\left(\mathrm{SO}_{4}{ }^{2-}\right)$ analyses were also conducted using the TRAACS 800 equipment also fitted with $10 \mathrm{~mm}$ x $0.5 \mathrm{~mm}$ diameter flow cell but using a $660-\mathrm{nm}$ filter as described by Clesceri et al. (1998).

\subsubsection{Metal analysis, Quality Assurance and Metal Limits of Detection (LOD)}

Mineral acid digestion (MAD) following previously described method (Awofolu et al., 2005) was applied for the isolation of metallic content in water samples. Quality assurance of the applied method was carried out through metal standard addition procedure of double-distilled water at fortification levels of $0.05 \mathrm{mg} / \mathrm{L}$ of $\mathrm{As}$ and $\mathrm{Cd}, 5.0 \mathrm{mg} / \mathrm{l}$ of $\mathrm{Fe}, \mathrm{Cu}$ and $\mathrm{Zn}$ was applied. Triplicate analyses of each metal together with a blank were carried out.

Metal limits of detection were carried out as three times the standard deviation $(3 \alpha)$ of their lowest detectable concentrations from the mean of six replicate analyses. Good linearity was obtained from the calibration curves prepared from $1,000 \mathrm{mg} / \mathrm{L}$ of each metal standard purchased from Hanna Inc. Johannesburg, South Africa. Iron (Fe), Cadmium (Cd), Copper $(\mathrm{Cu})$, Zinc $(\mathrm{Zn})$, and Arsenic (As), were determined using the Perkin Elmer dual View Model (optima) 4300 DV Inductively Coupled Plasma Atomic Emission Spectrometer (ICP-AES) as described by Clesceri et al. (1998).

\subsubsection{Analyses of Microbial Entities in Water Samples}

This was conducted to assess the health of the surface water from microbiological point of view since the surface water is utilised for domestic activities by informal settlers along the banks of the surface water. Heterotrophic (HT) bacteria count is usually carried out to reveal the general microbial quality of water while the Total Coliform (TC) bacteria analysis is conducted to show the general hygienic quality and integrity of the water. Faecal coliform/Escherichia coli analysis provides a reflection or presence of faecal pollution of the water. Hence, determination of these microbial indicators in water samples were carried out following the APHA (1992) standard methods.

\subsection{Statistical Analysis}

The Pearson Correlation Coefficient was applied to data to verify the relationship between some of the evaluated variables in water samples. The Accumulation Factor (AF), expressed 
as the ratio of the average level of a given variable downstream to the corresponding average level upstream (Fakayode, 2005; Bhat et al., 2014) was used to estimate the degree of contamination due to anthropogenic inputs. The magnitude of AF value of a variable relative to others indicates extent of accumulation. In this study, the upstream average value was based on values from BB1-BB4 (designated and used for deduction due to relatively fewer and moderate impactors within this section of the sampling points) while downstream average was based on values from BB5-BB9 (high impactors and used for deduction) along the stretch of the stream. The river recovery capacity (RRC) was calculated based on the previously described mathematical equation (Ernestova and Semenova, 1994; Fakayode, 2005; Bhat et al., 2014) as shown below:

$$
\mathrm{RRC}=\frac{\mathrm{X}_{\mathrm{o}}-\mathrm{X}_{1}}{\mathrm{X}_{\mathrm{o}}} \quad \mathrm{X} 100
$$

$\mathrm{X}_{\mathrm{o}}$ is the value of variable downstream and $\mathrm{X}_{1}$ is the corresponding value at upstream of the surface water where pollution is assumed to be relatively lower.

To verify whether significant differences exist between the sampling sites with respect to analysed variables, all data were analysed using one-way analysis of variance (ANOVA) at $P$ $<0.05$. Possible differences between analysed variables were also checked using 2-tailed t-test. All statistical analysis was performed using MS Excel data analysis.

\section{Results}

\subsection{Method Quality Assurance}

Result of the quality assurance of analysed trace metals as reflected by their recoveries as well as their detection limits are presented in Table 2.

Table 2. Detection limits $(\mu \mathrm{g} / \mathrm{l})$ and $*$ mean $\%$ recoveries $( \pm \mathrm{SD})$ of metal standards in deionised water

\begin{tabular}{|l|l|l|c|}
\hline Metals & Detection limits & Spiked amount & Recoveries \\
\hline $\mathrm{Cd}$ & 0.003 & 0.05 & $91.5 \pm 0.004$ \\
\hline $\mathrm{As}$ & 0.001 & 0.05 & $93.2 \pm 0.005$ \\
\hline $\mathrm{Fe}$ & 0.002 & 5.0 & $95.5 \pm 0.002$ \\
\hline $\mathrm{Zn}$ & 0.002 & 5.0 & $98.2 \pm 0.003$ \\
\hline $\mathrm{Cu}$ & 0.003 & 5.0 & $90.5 \pm 0.002$ \\
\hline
\end{tabular}

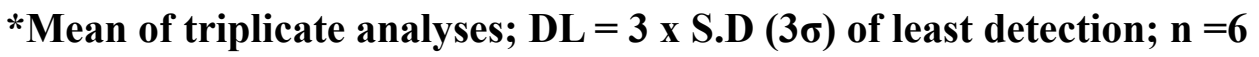

Recoveries from metal standard addition varied from $90.5 \pm 0.002-98.2 \pm 0.003 \mu \mathrm{g} / \mathrm{L}$ while metal detection limits ranged from 0.001, 0.003, 0.002, 0.002 and 0.00.3 $\mu \mathrm{g} / \mathrm{L}$ for As, Cd, Fe, $\mathrm{Zn}$ and $\mathrm{Cu}$ respectively. These are the various concentration levels at which each of the analysed trace metals can be determined.

\subsection{Physico-chemical Parameters}

Results of the physico-chemical variables in analysed water samples are presented in Table 3. 
Table 3. Level of the physico-chemical variables (mean $\pm \mathrm{SD}$ ) in analysed water samples

\begin{tabular}{|l|c|c|c|c|c|}
\hline Sampling points & pH values & $\mathbf{E C}(\mathbf{m S} / \mathbf{m})$ & $\mathbf{T S S}(\mathbf{m g} / \mathbf{L})$ & $\mathbf{T D S}(\mathbf{m g} / \mathbf{L})$ & $\mathbf{C O D}(\mathbf{m g} / \mathbf{L})$ \\
\hline BB1 & $7.4 \pm 0.4$ & $146.6 \pm 26.7$ & $19.3 \pm 23.0$ & $1001.3 \pm 214.7$ & $15.8 \pm 8.5$ \\
& $(6.8-7.9)$ & $(100-182)$ & $(10-80)$ & $(740-1308)$ & $(10-31)$ \\
\hline BB2 & $7.4 \pm 0.3$ & $93.0 \pm 24.0$ & $12.9 \pm 2.1$ & $590.3 \pm 153.0$ & $34.8 \pm 22.3$ \\
& $(7.0-7.6)$ & $(52-127)$ & $(10-16)$ & $(336-824)$ & $(10-81)$ \\
\hline BB3 & $7.7 \pm 0.3$ & $137.3 \pm 21.4$ & $28.8 \pm 28.6$ & $952.2 \pm 137.0$ & $21.9 \pm 15.5$ \\
& $(7.3-8.1)$ & $(99-171)$ & $(10-95)$ & $(718-1174)$ & $(10-58)$ \\
\hline BB4 & $8.0 \pm 0.2$ & $142.6 \pm 19.5$ & $11.3 \pm 3.30$ & $970.3 \pm 153.5$ & $15.6 \pm 7.8$ \\
& $(7.6-8.3)$ & $(116-179)$ & $(10-20)$ & $(800-1260)$ & $(10-30)$ \\
\hline BB5 & $8.3 \pm 0.2$ & $141.8 \pm 20.1$ & $18.1 \pm 11.7$ & $1020.3 \pm 147.6$ & $18.6 \pm 10$ \\
& $(7.7-8.2)$ & $(120-181)$ & $(10-44)$ & $(828-1220)$ & $(10-35)$ \\
\hline BB6 & $8.1 \pm 0.1$ & $134.4 \pm 14.6$ & $22.5 \pm 19.2$ & $912.5 \pm 133.3$ & $16.1 \pm 9.4$ \\
& $(7.8-8.5)$ & $(115-156)$ & $(10-60)$ & $(632-1070)$ & $(10-34)$ \\
\hline BB7 & $8.1 \pm 0.2$ & $122.5 \pm 12.0$ & $31.0 \pm 33.4$ & $853.0 \pm 81.1$ & $20.1 \pm 10.8$ \\
& $(7.9-8.4)$ & $(106-140)$ & $(10-112)$ & $(730-962)$ & $(10-42)$ \\
\hline BB8 & $8.2 \pm 0.1$ & $120.0 \pm 13.0$ & $30.5 \pm 28.9$ & $787 \pm 92.4$ & $24.3 \pm 13.6$ \\
& $(7.8-8.5)$ & $(103-138)$ & $(10-100)$ & $(676-908)$ & $(10-51)$ \\
\hline BB9 & $8.4 \pm 0.3$ & $123.0 \pm 13.5$ & $39.0 \pm 43.1$ & $796.5 \pm 123.7$ & $21.1 \pm 12.5$ \\
& $(7.6-8.7)$ & $100-140$ & $(10-147)$ & $(554-970)$ & $(10-44)$ \\
\hline
\end{tabular}

NB: Values in parentheses are range of variables; $B B=$ Blesbokspruit; 1-9 = sampling point; Values are mean of triplicate analysis

The mean $\mathrm{pH}$ values across the sampling periods ranged from $7.4-8.4$ with overall mean of 8.0. The lowest $\mathrm{pH}$ was recorded at sites $\mathrm{BB} 1$ and $\mathrm{BB} 2$, both at the upstream section of the sampling sites while the highest was recorded at BB9. The electrical conductivity (EC) values of water samples across sampling points varied from $93.0-146.6 \mathrm{mS} / \mathrm{m}$ while that of the Total Dissolve Solids (TDS) was 590.3 - $1020.3 \mathrm{mg} / \mathrm{L}$. Mean values for the chemical oxygen demand (COD) obtained across the sampling points was $15.6-34.8 \mathrm{mg} / \mathrm{L}$ while the total suspended solids (TSS) ranged from $11.3-39.0 \mathrm{mg} / \mathrm{L}$.

Results of the anionic variables in analysed water samples are as shown in Table 4 below.

Table 4. Level of anionic variables analysed in water samples of the Blesbokspruit

\begin{tabular}{|l|l|l|l|}
\hline Sampling points & $\mathbf{N O}_{3}{ }^{-}(\mathrm{mg} / \mathbf{L}) \mathbf{~ N}$ & $\mathbf{P O}_{4}{ }^{3-}(\mathrm{mg} / \mathbf{L})$ & $\mathbf{S O}_{4}{ }^{2-}(\mathbf{m g} / \mathbf{L})$ \\
\hline BB1 & $0.3 \pm 0.2(0.1-0.5)$ & $0.8 \pm 0.70(0.1-2.3)$ & $379.5 \pm 99.3(198-520)$ \\
\hline BB2 & $1.0 \pm 0.8(0.1-2.3)$ & $0.9 \pm 1.0(0.1-3.6)$ & $118.6 \pm 49(74-222)$ \\
\hline BB3 & $0.3 \pm 0.3(0.1-0.2)$ & $0.6 \pm 0.5(0.1-1.4)$ & $337.8 \pm 52.6(224-398)$ \\
\hline BB4 & $0.2 \pm 0.4(0.1-0.5)$ & $0.6 \pm 0.3(0.2-1.8)$ & $353.1 \pm 52.0(272-440)$ \\
\hline BB5 & $0.2 \pm 0.1(0.1-0.3)$ & $0.5 \pm 0.6(0.1-1.9)$ & $369 \pm 93.1(305-600)$ \\
\hline BB6 & $2.1 \pm 3.9(0.1-12.3)$ & $0.5 \pm 0.4(0.1-1.2)$ & $326.3 \pm 34.6(289-386)$ \\
\hline BB7 & $1.0 \pm 0.4(0.3-1.8)$ & $0.6 \pm 0.3(0.1-1.4)$ & $297.8 \pm 45.1(222-357)$ \\
\hline BB8 & $0.8 \pm 0.3(0.2-1.3)$ & $0.6 \pm 0.4(0.1-1.6)$ & $284.8 \pm 39.4(220-345)$ \\
\hline BB9 & $1.4 \pm 0.4(0.8-1.8)$ & $0.4 \pm 0.3(0.3-1.3)$ & $261.1 \pm 92.7(31-333)$ \\
\hline
\end{tabular}

NB: Values in parentheses are range of variables; $B B=$ Blesbokspruit; 1-9 = sampling point; Values are mean of triplicate analysis 
The mean values of nitrate varied from $0.16-2.01 \mathrm{mg} / \mathrm{L}$ across all sampled sites while that of phosphate and sulphate varied from $0.50-0.96 \mathrm{mg} / \mathrm{L}$ and $118.63-379.5 \mathrm{mg} / \mathrm{L}$ respectively.

\subsection{Level of Trace Metals in Surface Water}

The concentrations of trace metals in analysed water samples are as shown in Table 5.

Table 5. Concentration (mean $\pm \mathrm{SD}$ ) of heavy metals $(\mathrm{mg} / \mathrm{L})$ in analysed water samples from the Blesbokspruit

\begin{tabular}{|l|l|l|l|l|l|}
\hline Sampling points & As & Cd & Fe & Cu & Zn \\
\hline \multirow{2}{*}{ BB1 } & $0.03 \pm 0.02$ & $0.04 \pm 0.03$ & $0.08 \pm 0.06$ & $0.04 \pm 0.01$ & $0.07 \pm 0.01$ \\
& $(0.03-0.05)$ & $(0.02-0.07)$ & $(0.01-0.19)$ & $(0.01-0.04)$ & $(0.06-0.07)$ \\
\hline \multirow{2}{*}{ BB2 } & $0.02 \pm 0.01$ & $0.05 \pm 0.03$ & $0.73 \pm 0.6$ & $0.04 \pm 0.02$ & $0.08 \pm 0.01$ \\
& $(0.02-0.05)$ & $(0.02-0.07)$ & $(0.03-1.47)$ & $(0.01-0.04)$ & $(0.06-0.07)$ \\
\hline \multirow{2}{*}{ BB3 } & $0.05 \pm 0.01$ & $0.04 \pm 0.02$ & $0.12 \pm 0.1$ & $0.03 \pm 0.02$ & $0.12 \pm 0.1$ \\
& $(0.01-0.05)$ & $(0.02-0.08)$ & $(0.01-0.39)$ & $(0.01-0.04)$ & $(0.06-0.50)$ \\
\hline \multirow{2}{*}{ BB4 } & $0.04 \pm 0.01$ & $0.06 \pm 0.03$ & $0.04 \pm 0.02$ & $0.02 \pm 0.01$ & $0.06 \pm 0.01$ \\
& $(0.04-0.07)$ & $(0.02-0.06)$ & $(0.01-0.10)$ & $(0.01-0.04)$ & $(0.05-0.07)$ \\
\hline \multirow{2}{*}{ BB5 } & $0.05 \pm 0.03$ & $0.04 \pm 0.03$ & $0.13 \pm 0.22$ & $0.03 \pm 0.02$ & $0.07 \pm 0.02$ \\
& $(0.02-0.8)$ & $(0.01-0.08)$ & $(0.01-0.70)$ & $(0.02-0.05)$ & $(0.06-0.07)$ \\
\hline \multirow{2}{*}{ BB6 } & $0.05 \pm 0.01$ & $0.03 \pm 0.02$ & $0.10 \pm 0.09$ & $0.04 \pm 0.02$ & $0.05 \pm 0.01$ \\
& $(0.05-0.06)$ & $(0.03-0.07)$ & $(0.01-0.31)$ & $(0.01-0.04)$ & $(0.05-0.07)$ \\
\hline \multirow{2}{*}{ BB7 } & $0.01 \pm 0.02$ & $0.02 \pm 0.04$ & $0.18 \pm 0.1$ & $0.02 \pm 0.02$ & $0.15 \pm 0.05$ \\
& $(0.01-0.03)$ & $(0.02-0.07)$ & $(0.01-0.39)$ & $(0.01-0.04)$ & $(0.06-0.17)$ \\
\hline \multirow{2}{*}{ BB8 } & $0.04 \pm 0.02$ & $0.06 \pm 0.03$ & $0.25 \pm 0.3$ & $0.04 \pm 0.03$ & $0.08 \pm 0.01$ \\
& $(0.04-0.05)$ & $(0.02-0.08)$ & $(0.01-0.91)$ & $(0.01-0.12)$ & $(0.06-0.08)$ \\
\hline \multirow{2}{*}{ BB9 } & $0.06 \pm 0.02$ & $0.05 \pm 0.03$ & $0.19 \pm 0.1$ & $0.05 \pm 0.03$ & $0.06 \pm 0.01$ \\
& $(0.02-0.06)$ & $(0.02-0.07)$ & $(0.01-0.49)$ & $(0.01-0.14)$ & $(0.05-0.07)$ \\
\hline
\end{tabular}

NB: Values in parentheses are range of variables; $B B=$ Blesbokspruit; $1-9=$ sampling point; Values are mean of triplicate analysis

The mean level of Arsenic (As) ranged from $0.01-0.06 \mathrm{mg} / \mathrm{L}$ across the sampling periods while those for Cd varied from $0.02-0.06 \mathrm{mg} / \mathrm{L}$. Lowest and highest values of 0.02 and 0.06 $\mathrm{mg} / \mathrm{L} \mathrm{Cd}$ was obtained at sampling sites BB7 and BB8 respectively. Mean values of Fe varied from $0.04-0.73 \mathrm{mg} / \mathrm{L}$ while that of $\mathrm{Cu}$ ranged from $0.02-0.05 \mathrm{mg} / \mathrm{L}$. The lowest value of $\mathrm{Fe}$ was recorded at BB4 (upstream) while the highest value was at BB8 (downstream). The mean concentration of $\mathrm{Zn}$ in analysed water samples varied from $0.06-0.15 \mathrm{mg} / \mathrm{L}$.

\subsection{Level of Microbial Entities in Analysed Surface Water}

The mean values of microbial parameters in analysed water samples from the Blesbokspruit are shown in Table 6 below. 
Table 6. Concentration of microbial variables analysed in water samples of the Blesbokspruit

\begin{tabular}{|l|c|c|c|}
\hline $\begin{array}{l}\text { Sampling } \\
\text { points }\end{array}$ & $\begin{array}{l}\text { Faecal coliform } \\
(\mathbf{c f u} / \mathbf{1 0 0 m})\end{array}$ & $\begin{array}{l}\text { Total coliform } \\
(\mathbf{c f u} / \mathbf{1 0 0 m l})\end{array}$ & $\begin{array}{l}\text { Heterotrophic plate } \\
(\mathbf{c f u} / \mathbf{1} \mathbf{l})\end{array}$ \\
\hline BB1 & $20.6 \pm 13.0$ & $92.9 \pm 143.7$ & $7266.3 \pm 5033.2$ \\
& $(2.0-44)$ & $(7.0-470)$ & $39776 \pm 49$ \\
\hline BB2 & $44021 \pm 11957.1$ & $430294 \pm 506913.5$ & $(74-222)$ \\
\hline BB3 & $52.9 \pm 109$ & $674.9 \pm 1635.4$ & $10190 \pm 7384$ \\
& $(0-340)$ & $(4.0-5000)$ & $(1600-25700)$ \\
\hline BB4 & $15.9 \pm 18.4$ & $48.1 \pm 52.1$ & $4322.5 \pm 3760.7$ \\
& $(1.0-59)$ & $(13-180)$ & $(930-14000)$ \\
\hline BB5 & $61.8 \pm 84.3$ & $162.4 \pm 192.9$ & $9560 \pm 12096.4$ \\
& $(8.0-280)$ & $(20-620)$ & $20350 \pm 25128.6$ \\
\hline BB6 & $772 \pm 988$ & $5205 \pm 5835.5$ & $(1410-83000)$ \\
\hline BB7 & $(10-2900)$ & $(180-18000)$ & $22712.5 \pm 19243.4$ \\
& $1035.4 \pm 1303.9$ & $8633.8 \pm 12208.4$ & $(3900-68000)$ \\
\hline BB8 & $(24-3600)$ & $(250-39000)$ & $39365.7 \pm 53054.1$ \\
& $16878.5 \pm 3072.5$ & $16018.5 \pm 20339.8$ & $(3160-213800)$ \\
\hline BB9 & $(0-9700)$ & $(28-66000)$ & $36800 \pm 33563.0$ \\
& $1936.3 \pm 4003.6$ & $18403.8 \pm 29383.3$ & $(6000-105000)$ \\
\hline
\end{tabular}

The level of Faecal coliform (FC) obtained across sampled sites ranged from 20.63 - 44021 cfu/100ml, Total coliform (TC) varied from $92.88 \mathrm{cfu} / 100 \mathrm{ml}-430,294 \mathrm{cfu} / 100 \mathrm{ml}$ while the Heterotopic Plate Count (HPC) also varied from 10,190 cfu/100ml - 397,775 cfu/100ml.

\subsection{Correlation Analysis, ANOVA and Accumulation Factor}

Results of the correlation analysis for the physico-chemical parameters are presented in Table 7a. Correlation of 0.99 was obtained between EC and TDS; 0.51 between pH and TDS and strong negative correlation between E.C and COD

Table 7a. Correlation analysis of physico-chemical variables in water samples

\begin{tabular}{|l|r|r|r|r|r|}
\hline & \multicolumn{1}{|c|}{$p H$} & $E C(m S / m)$ & $T S S(m g / L)$ & $T D S(m g / L)$ & $C O D(m g / L)$ \\
\hline$p H$ & 1 & & & & \\
\hline$E C(m S / m)$ & 0.16 & 1 & & & \\
\hline$T S S(m g / L)$ & 0.51 & -0.07 & 1 & & \\
\hline$T D S(m g / L)$ & 0.18 & 0.99 & -0.10 & 1 & \\
\hline$C O D(m g / L)$ & -0.34 & -0.92 & -0.04 & -0.89 & \\
\hline
\end{tabular}

Results of the correlation analysis of trace metals in water samples are as shown in Table $7 \mathrm{~b}$. 
Table $7 b$. Heavy metals correlation analysis in water samples

\begin{tabular}{|l|r|r|r|r|r|}
\hline & \multicolumn{1}{|c|}{$A s$} & \multicolumn{1}{|c|}{$C d$} & \multicolumn{1}{c|}{ Fe } & \multicolumn{1}{c|}{ Cu } & \multicolumn{1}{c|}{ Zn } \\
\hline$A s$ & 1 & & & & \\
\hline$C d$ & 0.36 & 1 & & & \\
\hline$F e$ & -0.33 & 0.20 & 1 & & \\
\hline$C u$ & 0.50 & 0.25 & 0.30 & 1 & \\
\hline$Z n$ & -0.47 & -0.52 & 0.07 & -0.53 & 1 \\
\hline
\end{tabular}

Correlation of 0.36 was recorded between $\mathrm{As} / \mathrm{Cd} ; 0.50$, As/Cu while negative correction of -0.47 was obtained between $\mathrm{As} / \mathrm{Zn} ;-0.33 \mathrm{As} / \mathrm{Fe} ;-0.53 \mathrm{Cu} / \mathrm{Zn}$

Results of the correlation analysis of microbial variables are presented in 7c.

Table 7c. Correlation analysis of microbial variables in water samples

\begin{tabular}{|l|r|r|r|}
\hline & FC $(c f u / 100 m l)$ & $T C(c f u / 100 m l)$ & HPC $(c f u / l m l)$ \\
\hline FC $(\mathrm{cfu} / 100 \mathrm{ml})$ & 1 & 1 & \\
\hline TC $(\mathrm{cfu} / 100 \mathrm{ml})$ & 0.94 & 0.53 & 1 \\
\hline HPC $(\mathrm{cfu} / 1 \mathrm{ml})$ & 0.68 & 1 & \\
\hline
\end{tabular}

From this table, $(\mathrm{r}=0.94)$ was obtained between $\mathrm{FC}$ and $\mathrm{TC}$ while an average correlation was recorded between FC and HPC as well as TC and HPC.

ANOVA: Assessment of the relationship between sampling sites and the analysed variables using one-way ANOVA test revealed P- values of $0.49,3.29 \times 10^{-30}, 0.002,1.31 \times 10^{-13}$ for the microbial, physico-chemical, metallic and anionic variables. Possible relationship among some variables within each of these groups using the t-test gave values of 0.05 between (TC and HPC); 0.06 (FC and HPC) and 0.34 (FC and TC) for the microbial group. Values of 1.97 $\mathrm{x} 10^{-11}$ (EC and TDS); $2.27 \times 10^{-12}$ (TDS and COD) and $2.46 \times 10^{-13}$ (pH and EC) were obtained for the physico-chemical group while $\mathrm{Cd}$ and $\mathrm{Zn}$ (0.004); $\mathrm{Cu}$ and $\mathrm{Zn} \mathrm{(0.0006);} \mathrm{Fe}$ and $\mathrm{Cu}(0.03)$ and $\mathrm{Cd}$ and $\mathrm{Cu}(0.13)$ were recorded for the metallic group. Values for the anionic group include those between $\mathrm{NO}_{3}{ }^{-}$and $\mathrm{SO}_{4}{ }^{2-}\left(4.29 \times 10^{-9}\right) ; \mathrm{PO}_{4}{ }^{3-}$ and $\mathrm{SO}_{4}{ }^{2-}\left(4.25 \times 10^{-9}\right)$ and $\mathrm{NO}_{3}{ }^{-}$and $\mathrm{PO}_{4}{ }^{3-}(0.38)$. All data were processed at $(\mathrm{P}<0.05)$

Results of the accumulation factor and the river recovery capacity of the spruit are presented in Table 8 below.

Table 8. Accumulation factor (AF) and river recovery capacity (RRC) of analysed variables in water samples the Blesbokspruit

\begin{tabular}{|l|r|r|r|r|r|r|r|r|r|r|}
\hline & \multicolumn{9}{|l|}{ Physico-chemical parameters } & \multicolumn{4}{l|}{ Trace metals } \\
\hline & pH & EC & TSS & \multicolumn{1}{l|}{ TDS } & COD & \multicolumn{1}{l|}{ As } & Cd & Fe & \multicolumn{1}{l|}{ Cu } & \multicolumn{1}{l|}{ Zn } \\
\hline AF & 1.01 & 0.99 & 1.56 & 1 & 0.91 & 1.03 & 0.8 & 0.71 & 1.16 & 0.98 \\
\hline RRC & 9.4 & -5.6 & 53.6 & -10.1 & -4.31 & 41.7 & 4 & -26.3 & 38 & -36.7 \\
\hline
\end{tabular}

$\mathrm{AF}=$ Accumulation factor; $\mathrm{RRC}=$ River recovery capacity $(\%)$ 
A range of $0.99-1.56$ (AF) was obtained for the physico-chemical parameters while the range obtained for the trace metals was from $0.71-1.16$. The RRC obtained ranged between $-5.6-9.4$ for the physico-chemical parameters and between $-36.7-4$ for the trace metals.

\section{Discussion}

\subsection{Quality Assurance of Analytical Protocol}

The high recovery of analysed metals from the quality assurance experimental process confirmed method applicability, hence reliability of the analytical process. The detection of metals at the low parts per billion (ppb) ranges ensures the detection of analysed metals in water samples.

\subsection{Physico-chemical Parameters}

The $\mathrm{pH}$ is an important indicator of water quality and health due to the influence it exerts on the solubility, biological and chemical activities of water constituents. The result showed that $\mathrm{pH}$ values across the sampling sites and periods remained steady from BB1-BB2, increased marginally up to site BB5, remained steady thereafter between BB6-BB7 and with a marginal increase again up to site BB9. This pattern might possibly be due to cumulative upstream contribution. This gradual trend towards alkalinity could be because of contributions from sewage effluents as well as possible erosional activities from agricultural farmlands. However, the $\mathrm{pH}$ values obtained were within the Target Water Quality (TWQ) range of $6.0-9.0$ for drinking water purposes (DWAF, 1996a). At this $\mathrm{pH}$ level, no significant effects on health due to toxicity of dissolved metal ions and protonated species or on taste are expected.

The electrical conductivity (EC) gives a measure of water conductivity as well as an indication of the level of inorganic constituents. It also has a direct relation with the total dissolve solids (TDS) in water. TWQ value of $45 \mathrm{mS} / \mathrm{m}$ and $300 \mathrm{mg} / \mathrm{L}$ were recommended for EC and TDS respectively (DWAF, 1996a). By these, all analysed water samples exceeded the recommended values. The high level of inorganic constituents may be due to erosional phenomenon of soil nutrients from agricultural farmlands along the spruit as well as effluents from sewage treatment plants. From the correlation analysis, the strong correlation obtained between EC and TDS revealed common source of contaminants and also reflects direct proportionality between the two variables. Average correlation $(r=0.51)$ was obtained between $\mathrm{pH}$ and TSS. Strong negative correlation $(r=-0.92)$ was however obtained between EC and COD. Chemical Oxygen Demand (COD) provide a measure of the level of oxidisable organic matter and an indication of dissolve oxygen level. It is not so much a variable of concern with respect to water for domestic use. However, a permissible level of $250 \mathrm{mg} / \mathrm{L}$ of $\mathrm{COD}$ in inland surface water for the protection of aquatic ecosystem was recommended (MoEF, 2005). All the COD values obtained in this study were below this limit.

Although, there is no recommended value for TSS (i.e. particles in water $>2$ microns) for human health protection, however, a value of $100 \mathrm{mg} / \mathrm{L}$ has been prescribed for safe aquatic ecosystem (DWAF, 1996b). The highest value of $39.0 \mathrm{mg} / \mathrm{L}$ of TSS obtained in the study was much less than the prescribed value for safe aquatic ecosystem, hence no adverse effect is expected on aquatic organisms. High level of TSS has been reported to cause acute and 
chronic physiological effects in aquatic organisms, affect fish habitat, breeding and survival (kjelland et al., 2015).

The presence of nitrate $\left(\mathrm{NO}_{3}{ }^{-}\right)$in water is beneficial to some aquatic plants; excess level can lead to eutrophication and loss of dissolved oxygen. Target Water Quality range of $0-6 \mathrm{mg} / \mathrm{L}$ of nitrate in surface water was specified by DWAF (1996a). The highest mean value of 2.1 $\mathrm{mg} / \mathrm{L}$ was obtained at site BB6 (Table 3) was well within the TWQ range, hence no adverse human health effect is expected upon consumption of the surface water. However, the range (0.1-12.3 $\mathrm{mg} / \mathrm{L})$ obtained specifically at this site BB6 was higher than the recommended TWQ range for the protection of human health. High level of nitrate in water consumed by infants may result in illness with symptoms such as shortness of breath and blue-baby syndrome which could result in death if untreated (USEPA, 2009).

As with nitrate, excess amount of phosphate in aquatic medium is not desirous and may lead to proliferation of algae with consequential impact on aquatic health. An acceptable limit of $5.0 \mathrm{mg} / \mathrm{L}$ of phosphate for the protection aquatic ecosystem was recommended (DWAF, 1996b). The mean levels of obtained in this study were within the limit hence, the propensity of algal and other plants growth is minimal. However continuous medium to long-term release of nitrogen and phosphate-rich irrigation water from integrated agricultural practices may initiate negative effects (Xiao-e et al., 2008).

Sulphates play an important role in water hardness and affect the aesthetics of water in terms of taste as odour due to the action of sulphur reducing bacteria. A range of $0-200 \mathrm{mg} / \mathrm{L}$ of $\mathrm{SO}_{4}{ }^{2-}$ in water for domestic use was recommended (DWAF, 1996a). All the mean values across sampled sites except for the value $(118.6 \mathrm{mg} / \mathrm{L})$ obtained at site BB2 were above this range. Upper range values of 222 (BB2) - $600 \mathrm{mg} / \mathrm{L} \mathrm{(BB5)} \mathrm{were} \mathrm{also} \mathrm{recorded} \mathrm{which}$ revealed that the water is highly laden with this salt. High level of sulphate in water may initiate the development of diarrhoea in sensitive and some non-adapted individuals as well as slight taste if consumed. This high sulphate level could have emanated due to run-off of top soil, especially those from agricultural land.

\subsection{Level of Trace Metals in Water Samples}

Trace metals are natural constituents of the earth's crust; however anthropogenic activities have contributed to their environmental prevalence (Tchounwou et al., 2012). Highest mean value of $0.06 \mathrm{mg} / \mathrm{L}$ of arsenic (As) was obtained in this study which was higher than the recommended TWQ value of $0.01 \mathrm{mg} / \mathrm{L}$ (DWAF, 1996a) for safe domestic water use as well as the $0.01 \mathrm{mg} / \mathrm{L}$ value for the protection of aquatic ecosystem (DWAF, 1996b). A range of $0.02-0.8 \mathrm{mg} / \mathrm{L}$ of arsenic (As) obtained at (BB5) was quite worrisome since continual exposure has been reported to lead to long-term health fatality (USEPA, 2006). Cd also recorded highest mean value of $0.06 \mathrm{mg} / \mathrm{L}$ in analysed water samples with the upper range of $0.08 \mathrm{mg} / \mathrm{L}$ at BB3 and BB8 which were higher than the recommended value of $0.005 \mathrm{mg} / \mathrm{L}$ for water intended for domestic use (DWAF, 1996a). This value was however lower than 0.15 $\mathrm{mg} / \mathrm{L}$ prescribed for the safety of aquatic ecosystem (DWAF, 1996b).

Continual consumption of the water could result in acute or irreversible effects of $\mathrm{Cd}$ 
associated with kidney failure (Jaishankar et al., 2014). Iron (Fe) is regarded as an essential element due to the role it plays in human physiology. Excess in human has been attributed to a condition called hemochromatosis as well as hemosiderosis (Turlin and Deugnier, 1998). The highest mean value of $0.73 \mathrm{mg} / \mathrm{L}$ (BB3) of Fe obtained was higher than the recommended TWQ range of $0.001-0.5 \mathrm{mg} / \mathrm{L}$ (DWAF, 1996a) and higher than the value of $0.32 \mathrm{mg} / \mathrm{L}$ reported in a similar study (Huser et al., 2011). Six out of nine sampling sites recorded values above this range hence; the surface water can be regarded as unsafe for domestic use. Copper $(\mathrm{Cu})$ is also considered as essential to life but could become toxic at elevated levels. Low concentration in water has been linked to brain damage in some mammals (DWAF, 1996a). The highest mean value of $0.04 \mathrm{mg} / \mathrm{L}$ of $\mathrm{Cu}$ obtained in this study was within the TWQ range of 0-1.0 mg/L (DWAF, 1996a) recommended for $\mathrm{Cu}$ in water intended for domestic use and is also within the recommended value of $0.3 \mathrm{mg} / \mathrm{L}$ (DWAF, 1996 b) for the protection of aquatic ecosystem.

Although, $\mathrm{Cu}$ is regarded as an essential element, ingestion at higher concentrations can lead to gastrointestinal problems with possible damage to the liver, kidney and red blood cells (DWAF, 1996a). Zinc (Zn) generally is considered to possess low toxicity in human due to usage in food supplements. Higher amount however has been linked to gastrointestinal disturbance, dizziness and fatigue (Boreiko, 2010). TWQ range of $0-3 \mathrm{mg} / \mathrm{L}$ of $\mathrm{Zn}$ has been recommended (DWAF, 1996a). At this level, no aesthetic or human health effect is expected. The highest mean value of $0.15 \mathrm{mg} / \mathrm{L}$ of $\mathrm{Zn}$ obtained across the sampled sites and period as well as the highest range of $0.06-0.50 \mathrm{mg} / \mathrm{L}$ obtained at site BB3 was lower than the recommended value. Hence, no health effect associated with domestic use of the surface water is expected. The TWQ value of $\mathrm{Zn}$ in water for safe aquatic ecosystem was $0.002 \mathrm{mg} / \mathrm{L}$ (DWAF, 1996b). By this value, the water is not fit for the sustenance of aquatic ecosystem.

In terms of possible relationship between the analysed metals, the correlation indicator revealed low correlation between the metals. This possibly indicates varied sources of the metals in water samples. Different industries and entities are located along the spruit and they may all be releasing trace metals into the water body.

\subsection{Level of Microbial Entities in Water Samples}

Escherichia. coli, comprising of about $97 \%$ of coliform bacteria is normally used to confirm the presence of faecal pollution by human and animal in several aquatic media. These bacterial pathogens are known to cause diseases such as salmonellosis, dysentery, gastroenteritis and typhoid fever (Crum-Cianflone, 2008). TWQ value of $0 \mathrm{cfu} / 100 \mathrm{ml}$ has been recommended for water intended for domestic use (DWAF, 1996a). Highest mean value of $16878.5 \mathrm{cfu} / 100 \mathrm{ml}$ as well as highest range of $140-340000 \mathrm{cfu} / 100 \mathrm{ml}$ (BB2) were obtained in this study. Possible sources of this group of coliforms include municipal effluent and run-off from agricultural activities. Faecal coliform greater than $20 \mathrm{cfu} / 100 \mathrm{ml}$ pose a significant and increasing risk of infectious disease transmission. Prevalence of faecal coliform bacteria have been reported in the South African water system (Pitman, 2011).

Total coliform (TC) is normally used to assess water hygiene, water treatment efficiency and integrity of the distribution system. Ideally, TC bacteria should not be present in any water 
intended for consumption. However, a TWQ range of 0-5 counts/100 $\mathrm{ml}$ was recommended (DWAF, 1996a). At this range, the risk of microbial infection is deemed negligible. The mean values and range of TC obtained in this study were above this recommended range. Possible sources of this high contamination include improperly treated sewage, poor sanitary practices by informal settlers along the water channel and erosional effects from agricultural land. Significant and increasing risk of infectious disease transmission is highly expected from consumption of this water. The Heterotrophic Plate Count (HPC) is used to assess the general microbial quality of water and efficiency of disinfection processes. It is utilised in detecting certain bacteria amenable to growth under specific conditions. Bacteria such as Klebsiella, Citrobacter, Aeromonas and Yersinia spp. fall under this category. A TWQ range of $0-100$ count/1 ml has been recommended (DWAF, 1996a). Risk of microbial infection and disease transmission is very high considering the mean values and ranges (Table 5) obtained in this study. Correlation analysis however, revealed strong association between FC and TC while average correlation was shown between TC and HPC. These correlations could indicate similar sources of the microbial variables in the water body.

\subsection{Accumulation Factor (AF), River Recovery Capacity (RRC) and ANOVA}

The AF and RRC of the physico-chemical and trace metal variables are presented in Table 8 . Results of the AF showed that there was no significant difference in the values of analysed variables at both up- and downstream section of the water channel. This however, indicated the prevalence of the variables across the sampled points. This could also be due to continual release of variables by impactors from the upstream section of the study area. Of concern were the AF values of $1.56(\mathrm{TSS})$ and $1.16(\mathrm{Cu})$ obtained which could impact negatively on the health of the aquatic system. Low recovery values were obtained for As (42\%) and $\mathrm{Cu}$ $(38 \%)$ while average recovery was obtained for TSS (54\%). This indicated the released of analysed variables at a rate that was beyond the capacity of the aquatic system. These variables (EC, TDS, COD, Fe and $\mathrm{Zn}$ ) recorded negative recovery values. This indicate high burden of the aquatic system with respect to these variables as they are present/released at the rate that was beyond the recovery capacity of the system.

The sampling sites were not significantly different $(\mathrm{P}>0.05)$ with respect to microbial variables in analysed water samples. However, significant difference was observed between the sites and physico-chemical, metallic and anionic $(\mathrm{P}<0.05)$ variables. T-test between the variables TC and HPC; FC and HPC and FC and TC were not significant at $(\mathrm{P}<0.05)$ while significant differences were found between EC and TDS; TDS and COD and $\mathrm{pH}$ and EC all at $(\mathrm{P}<0.05)$. Significant difference also occurs between $\mathrm{Cd}$ and $\mathrm{Zn} ; \mathrm{Cu}$ and $\mathrm{Zn} ; \mathrm{Fe}$ and $\mathrm{Cu}(\mathrm{P}$ $<0.05)$ while the interaction between $\mathrm{Cd}$ and $\mathrm{Cu}$ was not significant all at $(\mathrm{P}>0.05)$. Interaction between the anions shows significant difference between $\mathrm{NO}_{3}{ }^{-}$and $\mathrm{SO}_{4}{ }^{2-}$ and $\mathrm{PO}_{4}{ }^{3-}$ and $\mathrm{SO}_{4}{ }^{2-}(\mathrm{P}<0.05)$ while that between $\mathrm{NO}_{3}{ }^{-}$and $\mathrm{PO}_{4}{ }^{3-}$ was not significant at $(\mathrm{P}>0.05)$. In generally, the sampling sites were significantly different with respect to the physico-chemical, elemental and anionic variables except for the microbial variables that were not significantly different. The post-hoc analysis showed no significant difference between the sampling points for both the factor and block levels. 


\section{Conclusion}

The study revealed the need to conduct assessment of the quality of natural water resources on a regular basis, identify potential impactors on water quality and institute mitigating measures. The Blesbokspruit is important especially when the water is utilised for domestic and other purposes. The detection of toxic trace metals such as $\mathrm{Cd}$ and As above target water quality limits as well as high level of faecal pollutants was quite worrisome in view of the health implications on human. The high conductivity values will also have serious impact on aquatic life. Water plays a major role in economic development and if this resource is not protected, the consequences are innumerable especially for a semi-arid country. Hence, monitoring of the activities of various impactors on the stream regular monitoring of the quality of the surface water is recommended.

\section{Acknowledgement}

The authors would like to thank the Department of Water Affairs, Resource Quality Services, South Africa for the assistance with sample analysis.

\section{References}

APHA. (1992). American Public Health Association. Standard Methods for the Examination of Water and Waste Water, $18^{\text {th }}$ Edn. Water Environment Federation, APHA, AWWF Publishers, Washington DC, USA.

Awofolu, O. R., Mbolekwa, Z., Mtshemla, V., \& Fatoki, O. S. (2005). Levels of trace metals in water and sediment from Tyume River and its effects on an irrigated farmland. Water SA, $31,87-94$.

Bernhoft, R. A. (2013). Cadmium Toxicity and Treatment: A review. The Scientific World J., 2013. https://doi.org/10.1155/2013/394652

Bhat, S. A., Meraj, G., Yaseen, S., \& Panditi, A. K. (2014). Statistical Assessment of Water Quality Parameters for Pollution Source Identification in Sukhnag Stream: An Inflow Stream of Lake Wular (Ramsar Site), Kashmir Himalaya. Journal of Ecosystems, 2014, 1-18

Boreiko, C. (2010). Overview of Health Risk Assessment for Zinc. Journal Toxicology and Environmental Health, Part A, 73, 166-174.

Clesceri, L. S., Greenberg, A. E., \& Eaton, A. D. (1998). "Standard Methods for the Examination of Water and Wastewater", $20^{\text {th }}$ Edition, American Public Health Association, 1015 Fifteenth Street NW Washington DC, pp. 2005-2605

Crum-Cianflone, N. F. (2008). Salmonellosis and the GI Tract: More than Just Peanut Butter. Current Gastroenterology Reports, 10(4), 424-431.

Duruibe, J. O., Ogwuegbu, M. O. C., \& Egwurugwu, J. N. (2007). Heavy metal pollution and human biotoxic effects. International Journal of Physical Science, 2, 112-118.

DWAF. (1996a). Department of Water Affairs and Forestry. South African Water Quality Guidelines" $2^{\text {nd }}$ edn, 1: Domestic Water Use, pp. 1-185. 
DWAF. (1996b). Department of Water Affairs and Forestry. South African Water Quality Guidelines $1^{\text {st }}$ edn. Aquatic Ecosystems, 7,. 1-159.

DWAF. (2004). Department of Water Affairs and Forestry. Upper Vaal Water Management Area: Internal Strategic Perspective. National Water Resource Planning, DWAF Report No P WMA 08/000/00/0304.

DWAF. (2006). Department of Water Affairs and Forestry. Wastewater Treatment in South Africa: "From Crisis to Compliance", pp. 28-30.

Ernestova, L. S., \& Semenova, I. V. (1994). The self-purification capacity of natural water as an indicator of the ecological state of a water body. Water Resources, 21, 146-150.

Fakayode, S. O. (2005). Impact assessment of industrial effluent on water quality of the receiving Alaro River in Ibadan, Nigeria. African Journal of Environmental Assessment \& Management, 10, 1-13.

Gamakaranage, C. S., Rodrigo, C., Weerasinghe, S., Gnanathasan, A., Puvanaraj, V., \& Fernando, H. (2011). Complications and management of acute copper sulphate poisoning; a case discussion. Journal of Occupational Medicine and Toxicology, 6(1), 34.

Hess, R., \& Schmid, B. (2002). Zinc supplement overdose can have toxic effects. Journal of Paediatric Haematology/Oncology, 24, 582-584.

Hoare, D., van der Merwe, E., \& Claasen, P. (2008). Ekurhuleni Metropolitan Municipality: Biodiversity Report, Ekurhuleni Metropolitan Municipality, Kempton Park, South Africa.

Huser, B. J., K̈ohler, S. J., Wilander, A., Johansson, K., \& F̈olster, J. (2011). Temporal and spatial trends for trace metals in streams and rivers across Sweden (1996-2009). Biogeosciences, 8, 1813-1823.

Jaishankar, M., Tseten, T., Anbalagan, N., Mathew, B. B., \& Beeregowda, K. N. (2014). Toxicity, mechanism and health effects of some heavy metals. Interdisciplinary Toxicology, 7, 60-72.

Keddy, K. H., Sooka, A., Ismail, H., Smith, A. M., Weber, I., Letsoalo, M. E., \& Harris, B. N. (2011). Molecular epidemiological investigation of a typhoid fever outbreak in South Africa, 2005: the relationship to a previous epidemic in 1993. Epidemiology and Infection, 139, 1239-1245.

Kjelland, M. E., Woodley, C. M., Swannack, T. M., \& Smith, D. L. (2015). A review of the potential effects of suspended sediment on fishes: potential dredging-related physiological, behavioral, and transgenerational implications. Environment Systems and Decisions, 35, 334-350

Masere, T. P., Munodawafa, A., \& Chitata, T. (2012). Assessment of human impact on water quality along Manyame River. International Journal of Development and Sustainability, 1, 754-765 


\section{Macrothink

MoEF. (2005). Ministry of Environment and Forests. Central Pollution Control Board. Pollution Control Acts, Rules, and Notifications issued thereunder, 4th edn, New Delhi, CPCB, Ministry of Environment and Forests, pp. 897.

Nartey, V. K., Hayford, E. K., \& Ametsi, S. K. (2012). Assessment of the Impact of Solid Waste Dumpsites on Some Surface Water Systems in the Accra Metropolitan Area, Ghana. Journal of Water Resource and Protection, 4, 605-615.

NICD. (2016). National Institute for Communicable Diseases. Sporadic cases of typhoid in South Africa. Communicable Diseases Communiqué, 15, 6.

Pitman, W. V. (2011). Overview of water resource assessment in South Africa: current state and future challenges, Water SA, 37(5), 659-664.

Sanjay, M., Varsha, M. V., Madaan, N., Mudgal, A., \& Singh, R. B. (2010). Effects of toxic metals on human health. The Open Nutraceuticals Journal, 3, 94-99

Tchounwou, P. B., Yedjou, C. G., Patlolla, A. K., \& Sutton, D. J. (2012). Heavy metals toxicity and the environment. EXS, 101, 133-164.

Turlin, B., \& Deugnier, Y. (1998). Evaluation and interpretation of iron in the liver. Seminars in Diagnostic Pathology Journal, 15, 237-245.

USEPA. (2006). United States. Environmental Protection Agency. Arsenic in drinking water. Washington DC; Available from: http://www.epa.gov /safe water/arsenic/ index.html; accessed July 2016.

USEPA. (2009). United States. Environmental Protection Agency. Table of Regulated Drinking Water Contaminants. The National Primary Drinking Water Regulations (NPDWRs or primary standards), 816-F-09-004.

Wall, K. (2006). An investigation of the franchising option for water services operation in South Africa. Water SA, 32, 265-268.

Warburton, M. L., Schulze, R. E., \& Jewitt, G. P. W. (2012). Hydrological impacts of land use change in three diverse South African catchments. Journal of Hydrology, 414-415: 118-135.

Xiao-e, Y., Xiang, W., Hu-lin, H., \& Zhen-li, H. (2008). Mechanisms and assessment of water eutrophication. Journal of Zhejiang University Science B, 9, 197-209.

\section{Copyrights}

Copyright for this article is retained by the author(s), with first publication rights granted to the journal.

This is an open-access article distributed under the terms and conditions of the Creative Commons Attribution license (http://creativecommons.org/licenses/by/4.0/) 